\title{
The Search for Meaningful e-Learning at Canadian Universities: A Multi-Institutional Research Study
}

Vincent Salyers ${ }^{1}$, Lorraine Carter ${ }^{2}$, Alanna Carter ${ }^{3}$, Sue Myers ${ }^{4}$, and Penelope Barrett ${ }^{5}$ ${ }^{1}$ Mount Royal University, Canada, ${ }^{2}$ Nipissing University, Canada, ${ }^{3}$ International Learning Academy of Canada (ILAC), ${ }^{4}$ SIAST, Canada, ${ }^{5}$ Warners Bay Private Hospital, Australia

\section{Abstract}

While e-learning is now characterized by a past and trends within that past, there continues to be uncertainty about how e-learning is defined and conceptualized, whether or not we like e-learning, and whether or not it is as meaningful to us as face to face learning. The purpose of this study was to document the e-learning perceptions of students at three Canadian post-secondary institutions. Key components of e-learning courses including ease of navigation, course design, resource availability, and adequacy of e-learning supports and their impact on the student learning experience were also evaluated.

Based on a survey of students ( $n=1,377)$ as well as their participation in focus groups, the following are presented as important findings: the majority of students studying in e-learning courses at the three institutions represented in the study were women; ease of navigation, course design, and previous experience with e-learning consistently demonstrated a statistically significant predictive capacity for positive e-learning experiences; and students expressed less preference for e-learning instructional strategies than their faculty.

Study findings hold implications for e-learning faculty, instructional designers, and administrators at institutions of higher education in Canada and elsewhere where elearning is part of the institutional mandate. Additionally, further research into student perceptions of and experiences with e-learning is recommended.

Keywords: e-learning; mixed methods; navigation; design; infrastructure support; flexible learning 


\section{Introduction}

Among the many reasons that increasing numbers of first degree university students and returning adult learners are turning to e-learning, two in particular stand out. The first is student demand for flexibility in where and how they learn (Ali, 2012; Bichsel, 2013; Burge, 2011; Carter \& Salyers, 2013; Carter, Salyers, Page, Williams, Hofsink, \& Albl, 2012; Elliott, 2011; Hammersley, Tallantyre \& Le Cornu, 2013; Hanover, 2011; Higher Education Academy, 2013; Johnson, Smith, Willis, Levine \& Haywood, 2011; McLinden, 2013; Oye, Salleh \& Iahad, 2011; Salyers, Carter, Barrett \& Williams, 2010). The second is that, as never before, university students may be technologically sophisticated and looking for ways to better integrate technology with their learning lives (Bichsel, 2013; Dahlstrom, Walker \& Dziuban, 2013; Johnson, Smith, Willis, Levine \& Haywood, 2011; Tapscott, 2008).

As support of the second reason, university students have, in large measure, grown up with technology; they socialize, book vacations, bank, and shop through the web. There is also growing recognition of the personal savings of studying in ways that fit complex professional and family lives (Dahlstrom, Walker \& Dziuban, 2013; ITC, 2013). At the same time, controversy exists about whether those who use technology in other aspects of their lives also wish to use it for learning where the engagement is complex and the role of learner is significantly different than in other technology-supported situations (Cleveland-Innes, Garrison, \& Kilsen, 2008). While students may prefer to utilize technology to connect, communicate, and manage their lives, they may or may not have the requisite skills for success in technology-mediated and e-learning environments (Bolinger \& Inan, 2012; Dahlstrom, Walker \& Dziuban, 2013; J ohnson, Adams-Becker, Cummins, Estrada, Freeman \& Ludgate, 2013; Means, Toyama, Murphy, Bakia \&J ones, 2010; Yukawa, Kawano, Suzuki, Suriyon, \& Fukumura, 2008). Also of importance is that research demonstrates there are no differences between net generation and non-net generation students' use of technology, their preferences for it, and their behavioral characteristics (Bullen, Morgan \& Qayyum, 2011; Margaryan, Littlejohn \& Vojt, 2011; Palfrey, Gasser, Simun \& Barnes, 2009; Selway, 2009).

Although the intention of those who champion e-learning is to provide students access to superior educational experiences characterized by flexibility not possible 20 years ago, there continues to be uncertainty about how e-learning is defined and conceptualized, how best to integrate e-learning strategies into curricula, and whether or not e-learning is as meaningful to us as face to face learning. In order to assess the Canadian elearning landscape, a research team representing three undergraduate universities undertook a multi-site mixed methods study to determine the perceptions of faculty and students in relation to e-learning as a meaningful experience. Because of the magnitude of data collected, quantitative and qualitative results based on student and faculty responses are reported separately. This paper reports the student-based quantitative findings. 


\section{Review of the Literature}

\section{E-Learning Defined}

The words innovation and novelty derive from the same Latin root meaning something new and, ideally, improved. In an early definition of the verb to innovate, the desire to innovate is reported to "moveth all troublesome men" (Ellis, 2005, p. 13). Stated in more modern terms, the act of innovation can stir strong emotions. There is little doubt that the innovative nature of e-learning has generated strong feelings and opinions across the educational community as well as in our homes when we discuss education and in the corporate training sector where training has assumed new formats. Innovation is not something new to education. As societal needs, demands, and expectations change, so too must education, and such has been the case throughout history.

Reflecting on educational innovation in North America over the last twenty years, a number of concepts and practices come to mind: distance and online education, blended education, technology-supported education, and e-learning. While the first three of these can be considered in their own right, each is a subset of item four: e-learning. The language of e-learning has generated a unique quagmire with no consistent definition of e-learning in sight (Carter \& Salyers, 2013; Lowenthal \&Wilson, 2010; Moore, DicksonDeane \& Galyen, 2011; Sangra, Vlachopoulos \& Cabrera, 2012). Equally problematic are pedagogies that affect how teachers teach and students learn and the heightened role of technologies in what is otherwise a human exchange.

In this study, e-learning refers to an integration of pedagogy, content, and technologies within a teaching and learning context. E-learning can, therefore, include face-to-face (f2f) classrooms in which information technologies (e.g., learning management systems, video-conferencing and web-conferencing, mobile devices, multimedia and simulation, and so forth) are used; blended and web-enhanced learning environments also known as flipped or hybrid classrooms; and fully online learning environments. E-learning is also an experience that can occur synchronously, asynchronously, or as a combination of the two (Carter \& Salyers, 2013).

\section{Characteristics of Effective E-Learning Environments}

Higher education has become a competitive market grounded in flexible, accessible, user-centric learning experiences (Buzducea, 2010; Carter, Salyers, Page, Williams, Hofsink, \& Albl, 2012). In other words, students want to be able to access education in convenient environments where they are supported but also free to engage with materials in different ways. Flexibility includes how institutions think about time, place, instructional pace, delivery methods, and learner entry (Ahmed, 2010; Bichsel, 2013; Carter, Salyers, Page, Williams, Hofsink, \& Albl, 2012; Fisher, 2009; Hanover, 2011; ITC, 2013; Johnson, Smith, Willis, Levine \& Haywood, 2011; McLinden, 2013; Salyers, 
Carter, Barrett, \& Williams, 2010). How we teach and learn using e-learning strategies, though, is different from teaching and learning in a classroom where technology is not used. Pedagogically, the e-learning landscape requires a renewed commitment to the design of instruction that is student-centered and that incorporates effective teaching and learning principles in technology-mediated environments.

It is generally agreed that, in order to design effective e-learning environments, a number of stakeholder groups including subject matter experts, instructional designers, information technologists, and educational technologists should be engaged (Herrington, Reeves \& Oliver, 2010; Kanuka, 2006; Siragusa, Dixon \& Dixon, 2007; Steen, 2008). Moreover, a number of elements must be well-integrated into e-learning environments to ensure that they are effective. Quality e-learning environments should: 1) address the needs of diverse learners, 2) apply effective pedagogical strategies, 3) incorporate state of the art instructional design principles, 4) support multiple technologies, and 5) provide for flexible and interactive learning opportunities (Buzzetto-More, 2007; Hussin, Bunyarit \& Hussein, 2009; Moore, Dixon-Deane \& Galyen, 2011; Oblinger \& Oblinger, 2005; Orellana, Hudgins \& Simonson, 2009; Sun, Tsai, Finger, Chen \&Yeh, 2007).

\section{Student Perceptions of E-Learning}

Much of the current research related to student perceptions of e-learning has focused on student satisfaction, achievement, flexibility, motivation, and retention based on a particular delivery format such as blended, fully online, and so forth (Abrami, Bernard, Wade, Schmid, Borokhovski, Tamim, Surkes, Lowerison, Zhang, Nicolaidou, Newman, Wozney \& Peretiatkowicz, 2006; Bekele, 2010; Bekele \& Menchaca, 2008; Bernard, Abrami \& Wade, 2007; Zuvic-Butorac, Roncevic, Nemcanin, \& Nebic, 2011; Fetaji, 2007; Sun, Tsai, Finger, Chen \& Yeh, 2008). Many of these studies report variables such as satisfaction at the end of the course rather than prior to taking an e-learning course (Ahmed, 2010; Albert \& J ohnson, 2011; Eom, Wen, \& Ashill, 2006). Student perceptions of e-learning are higher when elements such as accessibility, design, organization, interactivity, and supports for e-learning are fully integrated into the course experience (Allen \& Seaman, 2013; Bentley, Selassie, \& Shegunshi, 2011; Brown \& Voltz, 2005; Siragusa, Dixon \& Dixon, 2007; Steen, 2008; Tseng, Lin \& Chen, 2011; Wang, 2006; Zuvic-Butorac, Roncevic, Nemcanin \&Nebic, 2011).

Designing effective e-learning environments poses a number of challenges, none the least of which include diversity of student learners, adequate institutional supports, faculty and student perceptions of e-learning strategies, and engagement in non-face to face (f2f) learning environments (Allen \& Seaman, 2006; Bolliger \& Wasilik, 2009; Cook, Ley, Crawford \& Warner, 2009; Georgina \& Olson, 2008; Kennedy, J ones, Chambers \& Peacock, 2011; Panda \& Mishra, 2007; Ward, Peters \& Shelley, 2010). Whether we consider e-learning to be a philosophy or method or niche experience, it does represent a commitment to meet the learning needs of today's students (Bates, 2005; Fisher, 2009). Despite differing views and understandings of e-learning, 
institutions are challenged to be committed and forward thinking in terms of how to meet the diverse and changing needs and expectations of all learner groups. In order to begin to address the changing e-learning needs of students, faculty, and post-secondary institutions and in light of rapidly changing e-learning landscape, the authors of this paper have explored the e-learning perceptions of students in three post-secondary institutions in Canada.

\section{Question for Investigation}

Repeated research evidence seems to suggest that students may continue to lack the knowledge, skills, and/ or time they require to experience e-learning in meaningful ways. Additionally, they may have different opinions of and experiences with e-learning. As a response to this situation, the purpose of this study was to evaluate key components of e-learning courses and environments including ease of navigation, course design, resource availability, technical ability, and adequacy of elearning supports and their impact on the student e-learning experience. Results of this study will be used to inform decisions at Canadian universities in the pursuit of excellence in e-learning. The specific question explored in the study was the following:

How predictive are the key components of e-learning as reflected in the literature for the enhancement of learning, active participation, comfort with e-learning technologies, adequacy of e-learning skills, enjoyment of e-learning, preference for elearning over face to face classes, and the development of e-learning skills of students enrolled in e-learning courses?

\section{Theoretical Orientation}

The theoretical orientation that guided the research is based on Khan's (2010) global elearning framework. The framework was developed as a means for guiding the planning, design, development, and evaluation of e-learning environments based on eight dimensions. Table 1 summarizes the focus and key activities of each dimension. 
Table 1

E-Learning Framework Summarized by Aguti, Walters \&Wills (2013)

\begin{tabular}{|c|c|c|}
\hline Dimension & $\begin{array}{l}\text { Focus on e-learning } \\
\text { environment }\end{array}$ & Specific components \\
\hline Pedagogical & Teaching and learning & $\begin{array}{l}\text { - Analysis of content, audiences, goals, } \\
\text { media, } \\
\text { - Organization and layout of e-learning } \\
\text { systems, } \\
\text { - Design strategies, methods and } \\
\text { approaches. }\end{array}$ \\
\hline Technological & $\begin{array}{l}\text { Technology } \\
\text { infrastructure }\end{array}$ & $\begin{array}{l}\text { - Infrastructure planning, } \\
\text { - } \quad \text { Hardware and software. }\end{array}$ \\
\hline $\begin{array}{l}\text { Interface } \\
\text { Design }\end{array}$ & Aesthetics and design & $\begin{array}{l}\text { - } \quad \text { Page, site, and content design, } \\
\text { - } \quad \text { Navigation, accessibility, } \\
\text { - } \quad \text { Usability testing. } \\
\end{array}$ \\
\hline Evaluation & $\begin{array}{l}\text { Assessment of } \\
\text { learning and } \\
\text { environment }\end{array}$ & $\begin{array}{l}\text { - } \text { Assessment of learners, } \\
\text { - Evaluation of instruction, } \\
\text { - Evaluation of learning environment, } \\
\text { - } \text { pvaluation of content development } \\
\text { - Evaluation of individuals involved in } \\
\text { content development, } \\
\text { Evaluation of institutional e-learning } \\
\text { program. }\end{array}$ \\
\hline Management & $\begin{array}{l}\text { Maintenance of } \\
\text { learning environment }\end{array}$ & $\begin{array}{l}\text { - Managing information distribution, } \\
\text { - Managing e-learning content } \\
\text { development, } \\
\text { - Managing e-learning environment. }\end{array}$ \\
\hline $\begin{array}{l}\text { Resource } \\
\text { Support }\end{array}$ & $\begin{array}{l}\text { Technical and human } \\
\text { resource support }\end{array}$ & $\begin{array}{l}\text { - Online support, } \\
\text { - } \quad \text { Teaching and learning support, } \\
\text { - Technical support, } \\
\text { - } \quad \text { Online and offline resources. }\end{array}$ \\
\hline Ethical & Social, cultural, digital & $\begin{array}{l}\text { - } \quad \text { Social and political influences, } \\
\text { - } \quad \text { Cultural diversity, } \\
\text { - } \quad \text { Learner diversity, digital divide, } \\
\text { - Legal issues. }\end{array}$ \\
\hline Institutional & $\begin{array}{l}\text { Administration, } \\
\text { academic affairs and } \\
\text { student services }\end{array}$ & $\begin{array}{l}\text { - Admissions, finances, payments, } \\
\text { - } \quad \text { Information technology services, } \\
\text { policies } \\
\text { - Graduation and grades. }\end{array}$ \\
\hline
\end{tabular}

The researchers were particularly interested in the pedagogical, technological, interface design, evaluation, and resource support dimensions and their impact on student elearning perceptions. Based on Khan's framework, an e-learning skills inventory (ESI) was developed and administered as part of the study. It is described later in this paper. 


\section{Study Design and Methods}

\section{Participating Institutions}

As previously noted, the study involved three post-secondary institutions. The lead university has an enrollment of nearly 12,000 credit students who take a variety of programs and courses leading to bachelor's degrees, applied degrees, university transfer courses, diplomas, and certificates. The second institution provides post-secondary technical education and skills training, and is recognized nationally and internationally for its educational innovation. This institution serves 26,000 distinct students with programs that touch every sector of the economy and provides a number of courses and programs through distance education. The third university enrolls nearly 6,500 full and part-time students. The majority of programs are at the undergraduate level although a growing number of graduate programs are offered by this university.

\section{Study Design}

This two-year three-phase project used a descriptive mixed-methods design. In Phase I of the project, the team developed a definition of e-learning, determined roles and tasks (e.g., PI, Co-PI, collaborators), discussed knowledge dissemination activities and issues of authorship, developed research instruments, and reviewed ethics approval processes at the three institutions. Ethics approval was sought and received from all three institutions. Phase II involved data collection and analysis as well as triangulation of qualitative and quantitative findings. Analysis occurred from December 15, 2012 to April 30, 2013. Phase III began in April 30, 2013 and was completed in January 31, 2014. Development of recommendations, including possible interventions and dissemination of knowledge, were part of the work of Phase III.

This mixed method study used a concurrent triangulation design to guide and facilitate data collection. In this approach, quantitative and qualitative data are collected at designated points and triangulated (Creswell, 2009; Creswell, Plano Clark, Gutmann, \& Hanson, 2003). Data are then compared in order to identify similarities, differences, gaps, and unanswered questions. Figure 1 provides a visual representation of the research design. Because this specific paper focuses exclusively on the quantitative findings of the study based on student responses, evaluation of the triangulation design by the reader is not possible. 


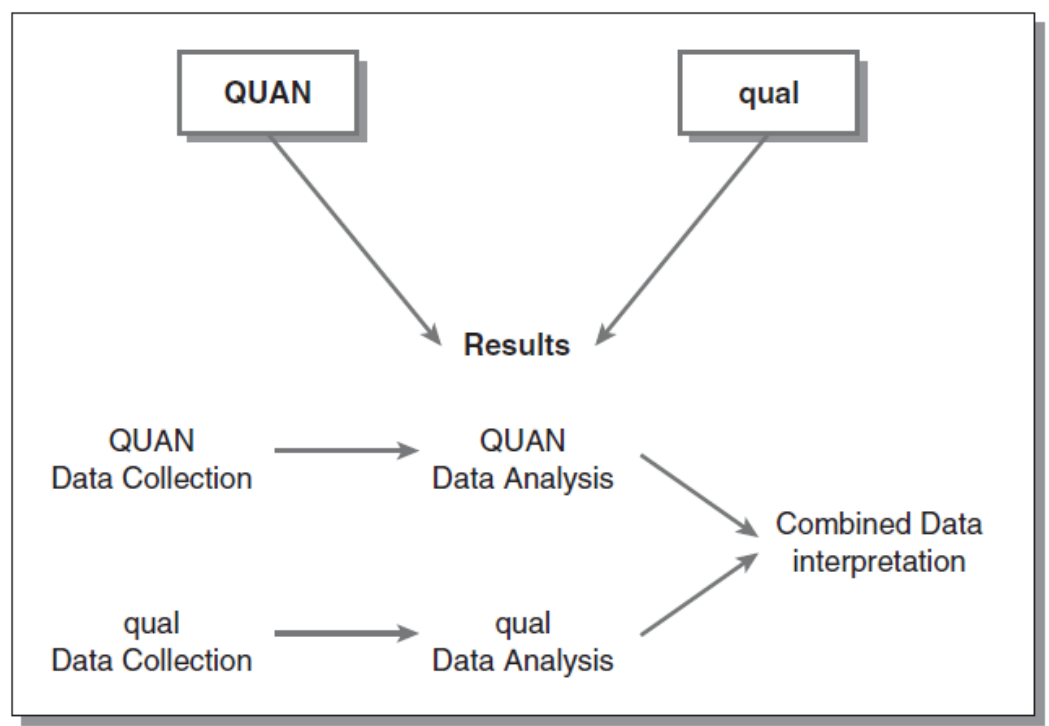

Figure 1. Concurrent triangulation design by Creswell, Plano Clark, Gutmann, \& Hanson (2003).

\section{Data Gathering}

The collection of quantitative data from students occurred concurrently from J anuary 1 , 2012 to December 15, 2012. Quantitative data were generated through online surveys. The participating sample was convenience based. Each institutional lead sought permission to invite undergraduate students from all faculties and schools to complete the survey made available through a live online link distributed through the university's email system.

The online survey distributed to students was developed by the research team who had consulted the literature and reviewed existing tools. The survey included 34 items that used a 5-point scale ( 1 = strongly disagree; 2 = disagree; 3 =agree; 4 = strongly agree; and 5 = not applicable) and functioned as an e-learning skills inventory (ESI). Areas covered in the survey included the following: level of knowledge regarding e-learning, prior experience using e-learning, access to e-learning and other resources, and general technology usage. Scale reliability for the student survey was calculated based on rank transformations. The internal consistency for the student ESI was $\alpha=.71$. This alpha coefficient is satisfactory based on using Nunnally's (1978) criterion of .70 as a cut-off point. Basic demographic information was also collected from students.

\section{Data Analysis}

All data were aggregated. Demographic profiles of the student participant groups were developed while descriptive and inferential statistics using SPSS 19.0 were generated based on the survey responses. Multiple regression analyses were conducted to evaluate 
the effectiveness of the independent variables-ease of navigation in the e-learning course, previous experience with an elearning course, e-learning course design, technical ability, availability of e-learning course support, and adequacy of resources-to predict seven dependent variables which were enhanced student learning, active student participation, comfort with the e-learning environment, adequacy of e-learning skills, enjoyment of e-learning, preference for taking e-learning courses, and the development of e-learning skills. Assumptions of independence, normality, homoscedasticity, and linearity were addressed. There were two instances where data were found to be outside the limits of skewness or kurtosis. They, however, were corrected for through rank transformations. Probability-probability (P-P) plots were generated for each multiple regression carried out and were linear in all instances, suggesting that the data were normally distributed.

\section{Findings}

\section{Demographic Profiles}

The study included a total of 1,377 student-participants across the three Canadian postsecondary institutions; the vast majority of the student-participants (76.7\%) were female. The two age categories most represented were 20-22 (27.1\%) and 17-19 (23.2\%). Asked about their levels of experience with e-learning, 33.0\% reported 2-4 years of experience taking courses that use elearning strategies; $30.7 \%$ of students reported $0-2$ years of experience with courses that use e-learning strategies. Table 2 summarizes student characteristics across the three institutions. 
Table 2

Demographic Profile of Survey Participants

\begin{tabular}{|l|l|}
\hline Total sample size & $\mathrm{n}=1346$ \\
\hline Gender* & \\
\hline Male & $310(22.9 \%)$ \\
\hline Female & $1039(76.7 \%)$ \\
\hline Other & $6(0.4 \%)$ \\
\hline Age* & \\
\hline $17-19$ & $316(23.2 \%)$ \\
\hline $20-22$ & $369(27.1 \%)$ \\
\hline $23-25$ & $215(15.8 \%)$ \\
\hline $26-28$ & $118(8.7 \%)$ \\
\hline $29-35$ & $133(9.8 \%)$ \\
\hline $35-64$ & $208(15.3 \%)$ \\
\hline$>64$ & $2(0.1 \%)$ \\
\hline Years taking courses using e-learning & \\
strategies* & \\
\hline $0-2$ & $397(30.7 \%)$ \\
\hline $2-4$ & $426(33.0 \%)$ \\
\hline $4-6$ & $280(21.7 \%)$ \\
\hline $6-8$ & $103(8.0 \%)$ \\
\hline $8-10$ & $34(2.6 \%)$ \\
\hline $10-12$ & $35(2.7 \%)$ \\
\hline$>12$ & $17(1.3 \%)$ \\
\hline Current institution & \\
\hline Post-secondary A & $816(59.3 \%)$ \\
\hline Post-secondary B & $456(33.1 \%)$ \\
\hline Post-secondary C & $104(7.6 \%)$ \\
\hline &
\end{tabular}

*This category had missing data (e.g., students did not complete this question). Percentages are calculated based on responses received.

\section{General Perceptions of E-Learning}

Student responses demonstrated consistent strong agreement or agreement on a crosssection of items. In general, the student data were positive with respect to e-learning: $80 \%$ of students strongly agreed or agreed that "e-learning technologies enhance my learning" while $84 \%$ strongly agreed or agreed with the statement that "overall, I have adequate e-learning skills to take courses using e-learning technologies."

Of the student-participants, $85 \%$ indicated that they had been comfortable using computers and software applications before they took an e-learning course. J ust over half (51\%) of students indicated agreement to strong agreement with the item that "elearning encourages me to participate more actively (in my learning)." Less than half (43\%) of students agreed or strongly agreed with the item "I prefer courses using elearning technologies more than traditional courses." 
Participants (97\%) believed that students in post-secondary institutions should be able to navigate in e-learning course environments. Students (84\%) strongly agreed or agreed that "students attending post-secondary institutions should have moderate to high e-learning skills." Moreover, students (85\%) agreed or strongly agreed that "the design of courses using e-learning strategies is important."

\section{Question One: E-Learning Components and Predictive Capacities}

Ease of navigation, course design, adequacy of e-learning supports, and previous experience with e-learning consistently emerged as having a statistically significant predictive capacity for each dependent variable. Statistically significant results and cumulative student $r$-square values for each regression analysis are provided in Tables 3-9.

Table 3

Regression Analysis - Dependent Variable: Enhanced Student Learning

\begin{tabular}{llllll}
$\begin{array}{l}\text { Independent } \\
\text { variable }\end{array}$ & $\begin{array}{l}\text { Parameter } \\
\text { estimate }\end{array}$ & $\begin{array}{l}\text { Standard } \\
\text { error }\end{array}$ & $\begin{array}{l}\text { Standardized } \\
\text { coefficients } \\
\text { Beta }\end{array}$ & $\begin{array}{l}\text { T for Ho: } \\
\text { Parameter=0 }\end{array}$ & Prob>|T| \\
\hline$\underline{\text { Students }}$ & & & & & \\
$\begin{array}{l}\text { Ease of navigation } \\
\text { in e-learning } \\
\text { courses }\end{array}$ & .392 & .036 & .365 & 10.922 & $.000^{* * *}$ \\
$\begin{array}{l}\text { Design of e- } \\
\text { learning } \\
\text { courses }\end{array}$ & .173 & .033 & .161 & 5.211 & $.000^{* * *}$ \\
$\begin{array}{l}\text { Adequacy of e- } \\
\text { learning supports }\end{array}$ & .112 & .036 & .108 & & \\
\hline
\end{tabular}

$\mathrm{R}^{2}$ (Students) $=.31 ; \mathrm{R}^{2}$ (Faculty) $=.23$

Note. ${ }^{*} \mathrm{p}<.05,{ }^{* *} \mathrm{p}<.01,{ }^{* * *} \mathrm{p}<.001$ 
Table 4

Regression Analysis - Dependent Variable: Active Participation

\begin{tabular}{llllll}
$\begin{array}{l}\text { Independent } \\
\text { variable }\end{array}$ & $\begin{array}{l}\text { Parameter } \\
\text { estimate }\end{array}$ & $\begin{array}{l}\text { Standard } \\
\text { error }\end{array}$ & $\begin{array}{l}\text { Standardized } \\
\text { coefficients } \\
\text { Beta }\end{array}$ & $\begin{array}{l}\text { T for Ho: } \\
\text { Parameter=0 }\end{array}$ & Prob $>|T|$ \\
\hline$\underline{\text { Students }}$ & & & & & \\
$\begin{array}{l}\text { Ease of navigation } \\
\text { in elearning } \\
\text { courses }\end{array}$ & .389 & .051 & .278 & 7.593 & $.000^{* * *}$ \\
$\begin{array}{l}\text { Previous } \\
\text { experience with e- } \\
\text { learning }\end{array}$ & .098 & .044 & .077 & 2.215 & $.027^{*}$ \\
$\begin{array}{l}\text { Adequacy of e- } \\
\text { learning supports }\end{array}$ & .140 & .052 & .103 & 2.685 & $.007^{* *}$ \\
\end{tabular}

$\mathrm{R}^{2}$ (Students) $=.18 ; \mathrm{R}^{2}$ (Faculty) $=.24$

Note. $* \mathrm{p}<.05, * * \mathrm{p}<.01, * * * \mathrm{p}<.001$

Table 5

Regression Analysis - Dependent Variable: Comfort with E-Learning Technologies

\begin{tabular}{llllll}
$\begin{array}{l}\text { Independent } \\
\text { variable }\end{array}$ & $\begin{array}{l}\text { Parameter } \\
\text { estimate }\end{array}$ & $\begin{array}{l}\text { Standard } \\
\text { error }\end{array}$ & $\begin{array}{l}\text { Standardized } \\
\text { coefficients } \\
\text { Beta }\end{array}$ & $\begin{array}{l}\text { T for Ho: } \\
\text { Parameter=0 }\end{array}$ & Prob $>|\mathrm{T}|$ \\
\hline$\underline{\text { Students }}$ & & & & 12.690 & $.000^{* * *}$ \\
$\begin{array}{l}\text { Ease of navigation } \\
\text { in e-learning } \\
\text { courses }\end{array}$ & .461 & .036 & .392 & & \\
$\begin{array}{l}\text { Previous } \\
\text { experience with e- } \\
\text { learning }\end{array}$ & .153 & .031 & .143 & 4.855 & $.000^{* * *}$ \\
$\begin{array}{l}\text { Design of e- } \\
\text { learning } \\
\text { courses }\end{array}$ & .206 & .034 & .174 & 6.058 & $.000^{* * *}$ \\
$\begin{array}{l}\text { Adequacy of e- } \\
\text { learning supports }\end{array}$ & .138 & .038 & .120 & 3.665 & $.000^{* * *}$ \\
\hline
\end{tabular}

$\mathrm{R}^{2}$ (Students) $=.18 ; \mathrm{R}^{2}$ (Faculty) $=.39$

Note. ${ }^{*} \mathrm{p}<.05,{ }^{* *} \mathrm{p}<.01, * * * \mathrm{p}<.001$ 
Table 6

Regression Analysis - Dependent Variable: Adequacy of E-learning Skills

\begin{tabular}{|c|c|c|c|c|c|}
\hline $\begin{array}{l}\text { Independent } \\
\text { variable }\end{array}$ & $\begin{array}{l}\text { Parameter } \\
\text { estimate }\end{array}$ & $\begin{array}{l}\text { Standard } \\
\text { error }\end{array}$ & $\begin{array}{l}\text { Standardized } \\
\text { coefficients } \\
\text { Beta }\end{array}$ & $\begin{array}{l}\text { T for Ho: } \\
\text { Parameter }=0\end{array}$ & Prob $>|\mathrm{T}|$ \\
\hline \multicolumn{6}{|l|}{$\underline{\text { Students }}$} \\
\hline $\begin{array}{l}\text { Ease of navigation } \\
\text { in e-learning } \\
\text { courses }\end{array}$ & .206 & .025 & .215 & 8.117 & $.000 * * *$ \\
\hline $\begin{array}{l}\text { Previous } \\
\text { experience } \\
\text { with e-learning }\end{array}$ & .422 & .022 & .487 & 19.255 & $.000 * * *$ \\
\hline $\begin{array}{l}\text { Adequacy of e- } \\
\text { learning supports }\end{array}$ & .061 & .026 & .066 & 2.354 & $.019 *$ \\
\hline $\begin{array}{l}\text { Design of e- } \\
\text { learning } \\
\text { courses }\end{array}$ & .196 & .024 & .203 & 8.256 & $.000^{* * * *}$ \\
\hline
\end{tabular}

Table 7

Regression Analysis - Dependent Variable: Enjoyment with Using E-Learning

\begin{tabular}{llllll}
$\begin{array}{l}\text { Independent } \\
\text { variable }\end{array}$ & $\begin{array}{l}\text { Parameter } \\
\text { estimate }\end{array}$ & $\begin{array}{l}\text { Standard } \\
\text { error }\end{array}$ & $\begin{array}{l}\text { Standardized } \\
\text { coefficients } \\
\text { Beta }\end{array}$ & $\begin{array}{l}\text { T for ho: } \\
\text { Parameter=0 }\end{array}$ & Prob $>|\mathrm{T}|$ \\
\hline$\underline{\text { Students }}$ & & & & & \\
$\begin{array}{l}\text { Ease of navigation } \\
\text { in e-learning } \\
\text { courses }\end{array}$ & .399 & .038 & .330 & 10.642 & $.000^{* * *}$ \\
$\begin{array}{l}\text { Previous } \\
\text { experience } \\
\text { with e-learning }\end{array}$ & .099 & .033 & .090 & 3.052 & $.002^{* *}$ \\
$\begin{array}{l}\text { Adequacy of e- } \\
\text { learning supports }\end{array}$ & .244 & .038 & .207 & 6.382 & $.000^{* * *}$ \\
$\begin{array}{l}\text { Design of e- } \\
\text { learning } \\
\text { Courses }\end{array}$ & .186 & .035 & .153 & 5.335 & $.000^{* * *}$ \\
\hline
\end{tabular}

$\mathrm{R}^{2}$ (Students) $=.55 ; \mathrm{R}^{2}$ (Faculty) $=.40$

Note. $* \mathrm{p}<.05, * * \mathrm{p}<.01, * * * \mathrm{p}<.001$ 
Table 8

Regression Analysis - Dependent Variable: Preference for E-Learning over Traditional Formats

\begin{tabular}{llllll}
$\begin{array}{l}\text { Independent } \\
\text { variable }\end{array}$ & $\begin{array}{l}\text { Parameter } \\
\text { estimate }\end{array}$ & $\begin{array}{l}\text { Standard } \\
\text { error }\end{array}$ & $\begin{array}{l}\text { Standardized } \\
\text { coefficients } \\
\text { Beta }\end{array}$ & $\begin{array}{l}\text { Tfor ho: } \\
\text { Parameter=0 }\end{array}$ & Prob $>|\mathrm{T}|$ \\
\hline Students & & & & &
\end{tabular}

\begin{tabular}{|c|c|c|c|c|c|}
\hline $\begin{array}{l}\text { Ease of navigation } \\
\text { in e-learning } \\
\text { courses }\end{array}$ & .461 & .053 & .316 & 8.772 & $.000^{* * *}$ \\
\hline $\begin{array}{l}\text { Previous } \\
\text { experience with e- } \\
\text { learning }\end{array}$ & .102 & .045 & .077 & 2.266 & $.024^{* *}$ \\
\hline $\begin{array}{l}\text { Adequacy of e- } \\
\text { learning supports }\end{array}$ & .185 & .053 & .131 & 3.468 & $.001^{* *}$ \\
\hline
\end{tabular}

Table 9

Regression Analysis - Dependent Variable: Development of E-Learning Skills

\begin{tabular}{llllll}
$\begin{array}{l}\text { Independent } \\
\text { variable }\end{array}$ & $\begin{array}{l}\text { Parameter } \\
\text { estimate }\end{array}$ & $\begin{array}{l}\text { Standard } \\
\text { error }\end{array}$ & $\begin{array}{l}\text { Standardized } \\
\text { coefficients } \\
\text { beta }\end{array}$ & $\begin{array}{l}\text { T for ho: } \\
\text { parameter=0 }\end{array}$ & Prob $>|\mathrm{T}|$ \\
\hline$\underline{\text { Students }}$ & & & &
\end{tabular}

$\begin{array}{llllll}\begin{array}{l}\text { Ease of navigation } \\ \text { in e-learning } \\ \text { courses }\end{array} & .136 & .031 & .157 & 4.393 & .000^{* * *}\end{array}$

Previous

$\begin{array}{lllllll}\text { experience with } \mathrm{e}- & .056 & .027 & .072 & 2.079 & .038^{*}\end{array}$
learning

Design of elearning .179 .029 .208

6.236 $.000 * * *$ courses

$\mathrm{R}^{2}$ (Students) $=.21 ; \mathrm{R}^{2}$ (Faculty) $=.29$

Note. ${ }^{*} \mathrm{p}<.05,{ }^{* *} \mathrm{p}<.01,{ }^{* * *} \mathrm{p}<.001$ 


\section{Discussion}

\section{Demographic Observations}

More female than male students participated in the study. This occurrence may be explained by the gender composition of the institutions involved in the study: in all three institutions, there are a number of professional programs (e.g., education, nursing, and so forth) in which there are more female students than male students. Alternately, this demographic may be reflective of those who take courses with elearning components more generally or the fact that the majority of university students in undergraduate programs in Canada are female (Canadian University Survey Consortium, 2013).

The need to understand the prevalence of females in this study as well as their elearning preferences goes beyond the first degree female student. In two of the universities, e-based programs are offered to working professionals. According to the literature, there are more females than men returning to university to upgrade their professional and employment skills (Carter \& Salyers, 2013; Salyers, Carter, Cairns \& Durrer, 2014). These students typically require the flexibility that e-based courses and programs can provide because they are the primary caregivers in families and have less time to attend face-to-face classes. Research is required into the concept of genderspecific attitudes and skills in relation to computer use and computer-assisted learning.

It is also worth reflecting on the idea that, while post-secondary students use technology widely in their lives, they seem to use technology when there is a convenience or gain such as online banking and / or for managing their lives. However, when it comes to matters such as learning in the context of a learning management system, it may be a different story. In many regards, these are platforms created to meet institutional needs.

\section{Predictors in E-learning}

As the regression analyses revealed, each of ease of navigation, course design, adequacy of e-learning supports, and previous experience with e-learning demonstrated a statistically significant predictive capacity for a positive e-learning experience. Two of these three items - ease of navigation and course design - underscore the criticality of instructional design in e-learning. While these ideas can be found in earlier e-learning literature (Zellweger, 2007, 2004), the study offers further evidence that instructional design expertise is vital to successful e-learning. As Laurillard (2013) comments, teaching today is nothing short of a design science and the need for excellence in instructional design has never been greater.

In virtually every context relevant to e-learning, the tasks of teaching (e.g., knowledge dissemination, skill development) and learning (e.g., acquiring new knowledge and skills, finding or making meaning) need to be combined with the technological aspects 
of delivery (e.g., use of a learning management system). This intersection requires ongoing assessment of the needs of the faculty and the student so that appropriate supports are developed and extended (Diaz, Garrett, Kinley, Moore, Schwartz \& Kohrman, 2009; Fang, 2007; Shepherd, Alpert \& Koeller, 2007; Taylor \& McQuiggan, 2008; Thompson, 2006). Immediacy and social presence are important characteristics of these supports. J ust in time technical support delivered in user friendly ways rather than workshops and training sessions are essential in e-learning (Berge \& Kendrick, 2005).

The final predictor found to be statistically significant ties to previous experience with elearning. This finding, in many regards, aligns with the responses to the first question. E-learning experience and e-skills play an important role in effective and positive experiences.

\section{Emerging Recommendations and Areas for Future Research}

While one could be inclined to place responsibility on the student for e-learning success, this would be short sighted. Both faculty members and the institution have responsibilities to carry out as well. Faculty, like students, need to have skills and experience levels equal to or greater than their students. Moreover, they need to recognize that e-teaching is different from teaching in other contexts and requires careful design and preparation carried out, ideally, with one or more colleagues with design expertise. Finally, e-learning requires ongoing support and this is where the university itself comes in. Institutional support for the vision of e-learning as well as just in time pedagogical and technical services sit at the heart of effectiveness in e-learning. Based on findings from this study, the following recommendations are offered:

1. Involve interprofessional teams of instructional designers, faculty, and individuals who support information technology in the development of elearning courses to increase the likelihood of success. While this may seem like an intuitive strategy, many universities may not have invested adequate institutional resources to support e-learning initiatives.

2. Evaluate the technical abilities, preferences, and experiences of students in order to design effective e-learning opportunities for them. Assumptions regarding the technical skills and savvy of today's university students need to be challenged. One means for doing so is through a fulsome assessment of the learners' abilities, skills, preferences, and experiences.

3. Establish design, navigation, pedagogy, and resources standards so that students develop comfort with e-learning environments and adequate elearning skills for success.

4. Develop and align e-learning strategies with academic and institutional strategic plans so that high quality e-learning courses are being delivered. Further, individuals responsible for academic planning and oversight should be involved in leading e-learning initiatives in order to acquire deep understanding of the complexity of e-learning. 
Looking forward, the researchers would argue that results of this study should be shared nationally and internationally: significantly, e-learning crosses borders and is proving to be a way of bringing education to those who previously may not have been able to access education. Steps are also needed to further understand faculty and student needs and to design interventions that respond to them. Replication of this study in other Canadian institutions and a non-Canadian context will uncover whether the trends in three Canadian institutions are reflective of e-learning as a broader phenomenon and how persons from different cultures approach e-learning. There is likewise a need to continue to engage e-learners and faculty in this dialogue and to investigate opportunities to work as co-researchers in e-learning.

In closing, given the uptake of e-learning at Canadian post-secondary institutions, the findings of this study are important and timely. Moreover, the findings point to areas in which additional and new research are required. Specifically, more research is required in the design, development, and delivery of exceptional e-learning experiences within institutional contexts and the human connection as supported by elearning environments.

\section{Limitations}

There are a number of limitations in this study. First, data collected from the surveys were self-reported and may have been subject to bias although a number of steps were taken to mitigate bias including the anonymous nature of the survey. Second, because standardized instruments were not used to collect data, reliability of the results may have been affected; however, alpha reliabilities were moderately high for the student survey. To minimize the limitations of response analysis used in this study, the researchers employed descriptive statistics and triangulation to maximize the reliability and validity of the findings. Regardless of these limitations, results from this study provide additional knowledge regarding e-learning from the student perspective.

\section{Acknowledgements}

The authors would like to thank Dr. Eun Um with the Statistical Consulting Group for her statistical analysis support. Appreciation is also extended to the National League for Nursing/Sigma Theta Tau International, as well as the Vice President, Academic \& Provost's Office at the lead university, for funding that supported student engagement in the research process and other aspects of the study. Special thanks to the research teams at each post-secondary institution for their participation and support throughout the research process. As well, special appreciation is expressed to the student researchers who participated as research team members. 


\section{References}

Ahmed, H. M. S. (2010).Hybrid e-learning acceptance model: Learner perceptions. Decision Sciences J ournal of Innovative Education, 8(2), 313- 346.

Albert, L., \&J ohnson, C. (2011). Socioeconomic status and gender-based differences in students' perceptions of e-learning systems. Decision Sciences J ournal of Innovative Education, 9(3), 421-36.

Aguti, B., Walters, R. \&Wills, G. (2013). A framework for evaluating the effectiveness of blended e-learning within universities. In R. McBride \& M. Searson (Eds.), Proceedings of Society for Information Technology \& Teacher Education International Conference 2013 (pp. 1982-1987). Chesapeake, VA: AACE.

Ali, W. (2012). Factors affecting nursing student's satisfaction with e-learning experience in King Khalid University, Saudi Arabia. International J ournal of Learning \& Development, 2(2), 201-15.

Allen, E., \& Seaman, J . (2013). Changing course: Ten years of tracking online in the United States. Babson Park, MA: Babson Survey Research Group and Quahog Research Group. Retrieved from: http:// faculty.washington.edu/rvanderp/ DLData/ AllenSeaman2013.pdf

Berge, Z. L., \& Kendrick A. A. (2005). Can interest in distance training be sustained in corporate organizations? International J ournal of Instructional Technology \& Distance Learning, 2(2). Retrieved from: http:// www.itdl.org/J ournal/Feb_05/article05.htm

Bichsel, J . (2013). The state of e-learning in higher education: An eye toward growth and increased access. Louisville, CO: Educause Center for Analysis and Research. Retrieved from: http:// net.educause.edu/ir/library/ pdf/ ers1304/ERS1304.pdf

Bolinger, D., \& Inan, F. (2012). Development and validation of the online student connectedness survey (OSCS). The International Review of Research in Open and Distance Learning, 13(3), 41-65.

Bolliger, D.U., \& Wasilik, O. (2009). Factors influencing faculty satisfaction with onlineteaching and learning in higher education. Distance Education, 30(1), 103-116.

Burge, E., Campbell Gibson, C., \& Gibson, T. (2011). Flexible pedagogy, flexible practice: Notes from the trenches of distance education. Athabasca, AB: AU Press. 
Bekele, T. A. (2010). Motivation and satisfaction in internet-supported learning environments: A review. Educational Technology \& Society, 13(2), 116-127.

Bekele, T. A., \&Menchaca, M. P. (2008). Research on Internet-supported learning: A review. Quarterly Review of Distance Education, 9(4), 373-406.

Bentley, Y., Selassie, H., \& Shegunshi, A. (2012). Design and evaluation of studentfocused e-Learning. Electronic J ournal of e-Learning, 10(1), 01-12.

Bullen, M., Morgan, T., \& Qayyum, A. (2011). Digital learners in higher education: Generation is not the issue. Canadian J ournal of Learning and Technology/ La revue canadienne del'apprentissage et de la technologie, 37(1), np. Retrieved from: http:// www.cjlt.ca/index.php/ cjlt/ issue/ view/ 71.

Buzducea, D. (2010). Social work in the new millennium: A global perspective. Social Work Review / Revista de Asistenta Sociala (1), 31-42.

Buzzetto-More, N. (2007). Advanced principles of effective e-learning. Santa Rosa, CA: Informing Science Press.

Canadian University Survey Consortium. (2013). 2013 First-year student survey. Prairie Research Associates.

Carter, L., \& Salyers, V. (2013). E-learning as educational innovation in Canada: Two case studies. In L. Shavinina (Ed.). International handbook of innovation education (pp. 442-55). New York: Taylor \& Francis/Routledge.

Carter, L., Salyers, V., Page, A., Williams, L., Hofsink, C., \&Albl, L. (2012). Highly relevant mentoring (HRM) as a faculty development model for web-based instruction. Canadian J ournal of Learning \& Technology, 38(1). Available at: http:/ / www.cjlt.ca/index.php/ cjlt/ article/ view/ 598

Cleveland-Innes, M., Garrison, R., \& Kinsel, E. (2008). The role of learner in an online community of inquiry: Responding to the challenges of first-time online learners. In N. Karacapilidis (Ed.). Solutions and innovations in web-based technologies for augmented learning: Improved platforms, tools and applications. Hersey, Penn.: IGI Global Publishing.

Cook, R. G. Ley, K., Crawford, C., \& Warner, A. (2009). Motivators and inhibitors for university faculty in distance and e-learning. British J ournal of Educational Technology, 1, 149-163. doi:10.1111/j.1467-8538.2008.00845.x

Dahlstrom, E., Walker, J ., \& Dziuban, C. (2013, Sept.). ECAR study of undergraduate students and information technology. Louisville, CO: EDUCAUSE Center for Analysis and Research. Retrieved from: https:// net.educause.edu/ir/library/pdf/ERS1302/ERS1302.pdf 
Daniel, J . (1998). Can you get my hard nose in focus? Universities, mass education and appropriate technology. In M. Eisenstadt \&T. Vincent (Eds.). The knowledge web. London: Kogan Page.

Davies, D., \& Graff, M. (2005). Performance in e-learning: online participation and student grades. British J ournal of Education Technology, 36, 657-663.

Diaz, V., Garrett, P., Kinley, E., Moore, J., Schwartz, C., Kohrman, P. (2009). Faculty development for the 21st century. Educause Review, 44(3), 46-55.

Fang, B. (2007). A performance-based development model for online faculty. Performance Improvement, 46(5), 17-24.

Half an hour: E-learning generations. Retrieved from: http:// halfanhour.blogspot.ca/2012/02/e-learning-generations.html

Ellis, A. (2005). Research on educational innovations (4th ed.). Eye on Education. Larchmont, NY.

Elliott, A. (2011). Increasing higher education access and pathways through normalization of flexible pedagogies and course structures. Proceedings of the 2011 Barcelona European Academic Conference, Barcelona, Spain. Retrieved on $05-17-14$

from: http:// conferences.cluteonline.com/index.php/IAC/2011SP/paper/viewF $\underline{\text { ile/ } 538 / 545}$

Eom, S. B., Wen, H. J ., \& Ashill, N. (2006). The determinants of students' perceived learning outcomes and satisfaction in university online education: An empirical investigation. Decision Sciences J ournal of Innovative Education, 4(2), 215235.

Fetaji, B. (2007). E-Learning literature review to investigate reasons of e-learning failures to meet the expectancies. In T. Bastiaens \& S. Carliner (Eds.), Proceedings of World Conference on E-Learning in Corporate, Government, Healthcare, and Higher Education 2007 (pp. 266-275). Chesapeake, VA: AACE. Retrieved May 24, 2014 from http:// www.editlib.org/p/26339

Fisher, R. (2009). Should we be allowing technology to remove the "distance" from “distance education”? New Zealand Annual Review of Education, 18, 31-46.

Georgina, D. A., \& Olson, M. R. (2008). Integration of technology in higher education: A review of faculty self-perceptions. Internet and Higher Education, 11, 1-8.

Guri-Rosenblit, S. (2005). 'Distance education' and 'e-learning': Not the same thing. Higher Education, 49(4), 467-493. 
Hammersley, A., Tallantyre, F., \& Le Cornu, A. (2013). Flexible learning: A practical guide for academic staff. York: Higher Education Academy. Retrieved from: http:// www.heacademy.ac.uk/resources/ detail/ flexiblelearning/fl_guides/staff_guide

Hanover Research (2011). Trends in global distance learning. Washington, DC.

Retrieved from: http://www.hanoverresearch.com/wpcontent/ uploads/ 2011/ 12/ Trends-in-Global-Distance-LearningMembership.pdf

Herrington, J ., Reeves, T. C., \& Oliver, R. (2010). A guide to authentic e-learning. New York: Routledge.

Higher Education Academy (2013). Flexible pedagogies: Technology-enhanced learning. Retrieved from: http:// www.heacademy.ac.uk/assets/ documents/ flexiblelearning/ Flexibl epedagogies/tech_enhanced_learning/TEL_report.pdf

Hussit, H., Bunyarit, F., \& Hussein, R. (2009). Instructional design and e-learning: Examining learners' perspective in Malaysian institutions of higher learning. Campus Wide Information Systems, 26(1), 4-19.

Instructional Technology Council (ICT, 2013). 2012 distance education survey results: Trends in e-learning: Tracking the impact of e-learning at community colleges. Washington, DC: ICT. Retrieved from: http:// www.itcnetwork.org/attachments/article/87/AnnualSurveyApril2 013.pdf

J ohnson, L, Adams-Becker, S., Cummins, M., Estrada, V., Freeman, A., \&Ludgate, H. (2013). NMC Horizon Report: 2013 Higher Education Edition. Austin, TX: The New Medium Consortium. Retrieved from: http:// www.nmc.org/ pdf/ 2013horizon-report-HE.pdf

J ohnson, L., Smith, R., Willis, H., Levine, A., \& Haywood, K. (2011). The 2011 horizon report. Austin, TX: The New Media Consortium. Retrieved from: http:// wp.nmc.org/ horizon2011/

Kanuka, M. (2006, Sept.). Instructional design and e-learning: A discussion of pedagogical content knowledge as a missing construct. e-J ournal of Instructional Science and Technology, 9(2). Retrieved from: http:// www.ascilite.org.au/ajet/ejist/docs/vol9_no2/papers/full_papers/kanuka.htm

Keegan, D. (1996). Foundations of distance education (3rd ed.). London: Routledge. 
Kennedy, G., J ones, D., Chambers, C., \& Peacock, J . (2011, Dec.). Understanding the reasons academics use - and don 't use - endorsed and unendorsed learning technologies. Proceedings of the Ascilite 2011 Changing Demands, Changing Directions Conference. Hobart Tasmania, Australia. Available at: http:// www.ascilite.org.au/conferences/hobart11/ downloads/ papers/ Kenne dy-full.pdf

Khan, B. H. (2010). The global e-learning framework. In B. Khan (Ed.), E-learning (pp.42-51). Retrieved

from: https:// webserver.ignou.ac.in/institute/STRIDE_Hb8_webCD/Chapter \%205.pdf

Ladyshewsky, R. (2004). E-learning compared with face to face: Differences in the academic achievement of postgraduate business students. Australasian J ournal of Educational Technology, 20(3), 316.36.

Laurillard, D. (2012). Teaching as design science: Building patterns for learning and technology. New York: Routledge.

Lowenthal, P., \&Wilson, B. G. (2010). Labels do matter! A critique of AECT's redefinition of the field. TechTrends, 54(1), 38-46

Margaryan, A., Littlejohn, A., \&Vojt, G. (2011). Are digital natives a myth or reality? University students' use of digital technologies. Computers \& Education, 56(2), 429-440.

Means, B., Toyama, Y., Murphy, R., Bakia, M., \&J ones, K. (2009). Evaluation of evidence-based onlinelearning: A meta-analysis and review of online learning studies. U.S. Department of Education Report, Office of Planning Evaluation and Policy Development, Policy and Program Studies Service, 1- 66. Retrieved from: http:// www2.ed.gov/ rschstat/ eval/tech/ evidence-basedpractices/finalreport.pdf

McIntosh, C., \& Varoglu, Z. (2005). Perspectives on distance education lifelong learning and distance higher education. British Columbia: Commonwealth of Learning.

McLinden, M. (2013). Flexible pedagogies: Part-time learners and learning in higher education. The Higher Education Academy, University of Birmingham, York: UK. Retrieved from: http:// www.heacademy.ac.uk/assets/ documents/ flexiblelearning/ Flexibl epedagogies/ptlearners/fp_ptl_report.pdf

Miles, M.B. \& Huberman, A.M. (1994). Qualitative data analysis: An expanded sourcebook. London: Sage. 
Moore, J ., Dickson-Deane, C., \& Galyen, K. (2011). E-learning, online learning, and distance learning environments: Are they the same? Internet \& Higher Education, 14, 129-35.

Nunnaly, J . (1978). Psychometric theory. New York: McGraw-Hill.

Oblinger, D., \& Oblinger, J . (2005). Educating the net generation. Louisville, CO: EDUCAUSE. Retrieved from: https:// net.educause.edu/ir/library/ pdf/ pub7101.pdf

Oye , N. D., Salleh, M., \&Iahad, N. A. (2011). Challenges of e-learning in Nigerian university education based on the experience of developed countries. International J ournal of Managing InformationTechnology, 3(2), 39-48.

Palfrey, J ., Gasser, U., Simun, M., \&Barnes, R.F. (2009). Youth, creativity and copyright in the digital age. International J ournal of Learning \& Media, 1(2), 79-97.

Panda, S., \& Mishra, S. (2007). E-learning in Mega Open University: Faculty attitudes, barriers and motivators. Educational Media International, 44(4), 328-38. Available at: $\underline{\text { http:// cohortresearch.wiki.westga.edu/file/ view/ faculty+attitude+barriers+ }}$ and+motivators.pdf

Rosenberg, H., Grad, H. A., \& Matear, D. W. (2003). The effectiveness of computer-aid, self- instructional programs in dental education: A systematic review of the literature. J ournal of Dental Education, 67(4), 524- 532.

Russell, T. L. (2001). The no significant difference phenomenon: A comparative research annotated bibliography on technology for distance education. Montgomery, AL: IDECC.

Salyers, V., Carter, L., Cairns, S., \&Durrer, L. (2014). The use of scaffolding and interactive learning strategies in online courses for working nurses: Implications for adult and online education. The Canadian J ournal of University Continuing Education, 40(1). Available online at: http:// ejournals.library.ualberta.ca/index.php/ cjuce-rcepu/article/ view/ 22199

Salyers, V., Carter, L., Barrett, P., \&Williams, L. (2010). Evaluating student and faculty satisfaction with a pedagogical framework. J ournal of Distance Education/ Revue de l'Éducation à Distance, 24(3).

Sangra, A., Vlachopoulos, D., \& Cabrera, N. (2012). Building an inclusive definition of e-learning: An approach to the conceptual framework. The International Review of Research in Open and Distance Learning, 13(2), Retrieved from: http:// www.irrodl.org/index.php/irrodl/article/view/ 1161/2146 
Selwyn, N. (2009). The digital native: Myth and reality. Aslib Proceedings: New Information Perspectives, 61(4), 364-379.

Shepherd, C., Alpert, M., \& Koeller, M. (2007). Increasing the efficacy of educators teaching online. International J ournal of Human and Natural Sciences, 2(3), 172-178.

Siemens, G. (2005). A learning theory for the digital age. Instructional Technology and Distance Education, 2(1), 3-10.

Siemens, G., \& Conole, G. (2011, special issue). Connectivism: Design and delivery of social networked learning. The International Review of Research in Open and Distance Learning, 12(3), i-iv.

Siemens, G. (2005). A learning theory for the digital age. Instructional Technology and Distance Education, 2(1), 3-10.

Sitzmann, T., K. Kraiger, D. Stewart, \& R. Wisher (2006). The comparative effectiveness of Web-based and classroom instruction: A meta-analysis. Personnel Psychology, 59, 623-64.

Sussman, S., \&Dutter, L. (2010). Comparing student learning outcomes in face-to-face and online course delivery. Online J ournal of Distance Learning Administration, 13(4), np. Retrieved from: http:// www.westga.edu/ distance/ ojdla/ winter134/sussman_dutter134. $\underline{\mathrm{html}}$

Tapscott. D. (2008). Grown up digital: How the net generation is changing your world. McGraw-Hill.

Taylor, A., \& McQuiggan, C. (2008). Faculty development programming: If we build it, will they come? Educause Quarterly, 31(3). Retrieved from: http:// www.educause.edu/EDUCAUSE+Quarterly/ EDUCAUSEQuarterly MagazineVolum/FacultyDevelopmentProgrammingI/163099

Thompson, D. (2006). Informal faculty mentoring as a component of learning to teach online: An exploratory study. Online J ournal of Distance Learning Administration, 9(3). Retrieved from: http:// www.westga.edu/ distance/ ojdla/ fall93/thompson93.htm

Titthasiri, W. (2013, Nov.). A comparison of e-learning and traditional learning: Experimental approach. Paper presented at the International Conference on Mobile Learning, E-Society and E-Learning Technology ( ICMLEET ) Singapore on November 6 - 7, 2013 
Tseng, M., Lin, R., \& Chen, H. (2011) Evaluating the effectiveness of e-learning system in uncertainty. Industrial Management \& Data Systems, 111(6), 869-89.

Ward, M., Peters, G., \& Shelley, K. (2010). Student and faculty perceptions of the quality of online learning experiences. International Review of Research in Open \& Distance Learning, 11(3), 57-77.

Wenger, E. (2004). Communities of practice: A brief introduction [Electronic version]. Retrieved on 05-25-14 from: http:// wenger-trayner.com/theory/

Wenger, E., McDermott, R., \& Snyder, W.M. (2002). Cultivating communities of practice. Boston: Harvard Business School Press.

Yukawa, T., Kawano, K., Suzuki, Y., Suriyon, T. \& Fukumura, Y. (2008). Implementinga sense of connectedness in e-learning. In J . Luca \& E. Weippl (Eds.), Proceedings of World Conference on Educational Multimedia, Hypermedia and Telecommunications 2008 (pp. 1198-1207). Chesapeake, VA: AACE.

Zellweger, F. (2004). Institutional EdTech support for faculty at research universities: Insights from a case study at the Massachusetts Institute of Technology (MTT). Paper presented at the World Conference on Educational Multimedia, Hypermedia and Telecommunications 2004, Lugano, Switzerland.

Zellweger Moser, F. (2007). Faculty adoption of educational technology. Educational technology support plays a critical role in helping faculty add technology to their teaching. EDUCAUSE Quarterly, 30(1), 66-69.

Zuvic-Butorac, M., Roncevic, N., Nemcanin, D., \&Nebic, Z. (2011). Blended e-learning in higher education: Research on students' perspective. Issues in Informing Science and Information Technology, 8, 409-29.

(C) Salyers, Carter, Carter, Myers, Barrett

\section{Athabasca University $\mathbf{a}$}

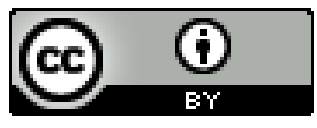

This work is licensed under a Creative Commons Attribution 4.0 International License. 